\title{
Trusted Advisors in a Family Business's Succession-Planning Process-An Agency Perspective
}

\author{
Alexandra Michel \\ University of St. Gallen \\ Center for Family Business \\ Dufourstrasse 40a \\ 9000 St. Gallen, Switzerland \\ Tel: +41712247100 \\ Fax: +41712247101 \\ e-mail: alexandra.michel@student.unisg.ch \\ Nadine Kammerlander \\ University of St. Gallen \\ Center for Family Business \\ Dufourstrasse 40a \\ 9000 St. Gallen, Switzerland \\ Tel: +417122471 16 \\ Fax: +41712247101 \\ e-mail: nadine.kammerlander@unisg.ch
}

\section{Paper accepted for publication in Journal of Family Business Strategy}

October 10, 2014

Keywords: family business, trusted advisor, succession planning, agency theory

\section{Highlights:}

- Synthesis of prior research on trusted advisors, family firm succession, and agency theory

- Decreased and increased agency costs of trusted advisor involvement

- Extension of literature on family business succession by moving from a dyadic relationship to a triadic relationship

- Discussion of constellations involving trusted advisors according to their level of bias and efficiency 


\title{
Trusted Advisors in a Family Business's Succession-Planning Process-An Agency \\ Perspective
}

\begin{abstract}
Family business succession is a complex and challenging process, in which family members often build on the support of trusted advisors who can be seen as the most relied external source of advice and knowledge that family businesses draw on. Based on an extensive literature review, this article aims to synthesize prior research on both advisors and succession to systematically describe and analyze the role of trusted advisors during the succession-planning process. Based on arguments from agency theory, we discuss potential benefits and drawbacks associated with the involvement of trusted advisors along the four phases - trigger, preparation, selection, and training - of the succession-planning process and outline how trusted advisors can mitigate but also enhance agency costs - in particular goal divergence and information asymmetry-during each of these four phases. Subsequently, we discuss four typical constellations of advisor involvement, which vary in their agency costs and thus have different levels of bias and efficiency. We thereby outline several inefficiencies that result from the common setup in which an incumbent and a successor both rely on their own trusted advisors or a team of expert advisors and propose a balanced and efficient model of advisor involvement as a potential solution which reduces the agency costs. This conceptual article contributes to research on succession, agency theory, and trusted advisors in family firms.
\end{abstract}

Keywords: family business, trusted advisor, succession planning, agency theory. 


\section{INTRODUCTION}

Family business succession is a crucial and in many cases long lasting process that may absorb the attention and resources of a family for years (Cabrera-Suarez, De Saa-Perez \& GarciaAlmeida, 2001). Numerous examples around the world show that succession is also a challenging process that many businesses struggle with (Mussolino \& Calabro, 2014), in particular with defining the right timing, finding the right successor, and managing the succession process in a fortunate way (Sharma, 2004).

In light of the challenges that arise during the succession process, researchers and practitioners have recently started to point to the crucial role played by trusted advisors in the succession process (e.g., Strike, 2012). Trusted advisors are defined as the most-relied external source of business advice for members of family businesses, including, for instance, lawyers, accountants, and consultants with whom family members have enjoyed long-lasting professional relationships (LaChapelle \& Barnes, 1998; Nicholson, Shepherd \& Woods, 2010). On the one hand, trusted advisors are expected to provide important capabilities such as expert knowledge and high-quality feedback and thus improve the quality of family members' decisions, the strategic planning process, and ultimately the firm's performance (Davis, Dibrell, Craig \& Green, 2013; Reay, Pearson \& Dyer, 2013; Strike 2012). In particular, trusted advisors can improve the efficacy of the succession process by mentoring both incumbents and successors, providing new insights on the succession (Salvato \& Corbetta, 2013), or acting as agents to bring different opinions together and achieve compromise solutions (Lane, Astrachan, Keyt \& McMillan, 2006; Thomas, 2002). However, trusted advisors are also associated with possible costs and drawbacks, stemming from agency costs, particularly those costs that result from divergent goals (e.g., Chrisman, Chua \& Sharma, 2004) and informational asymmetries (e.g., Dehlen, Zellweger, Kammerlander \& Halter, 2014) between the incumbent, the successor, and the advisor. Those 
drawbacks include heavy pressure on incumbents (Hilburt-Davis \& Senturia, 1995), an overly task-oriented approach that neglects involved parties' emotions (Goodman, 1998; Kaye, 1996), and narrow coaching that results in a reduction in the independence of successors' actions and decisions (Lane, 1989).

Despite recent advances in the scholarly knowledge about the influence of trusted advisors in family firms, our understanding of their role and its associated benefits and drawbacks is still superficial (see discussion in Strike, 2012). In particular, the precise benefits and disadvantages associated with trusted advisor involvement remain unclear to date. In addition, there is a lack of knowledge about the drivers of efficient and unbiased (as opposed to inefficient and biased) triadic constellations of incumbents, successors, and trusted advisors. We aim to contribute to closing this gap by integrating the abundant body of literature on the succession process (e.g., Sharma, 2004; Sharma, Chrisman \& Gersick, 2012) with the nascent research stream on family business advisors (e.g., Reay et al., 2013; Strike, 2012) and by building a conceptual model on the impact of involving a trusted advisor in a family business succession. Thereby, we consider leadership and ownership transfers to both family-internal and -external successors. Moreover, we concentrate on the "planning process" (Cabrera-Suarez et al., 2001; Sharma, Chrisman \& Chua, 2003), which is particularly determinative of the outcome of the succession process (De Massis, Chua \& Chrisman, 2008; Le Breton-Miller, Miller \& Steier, 2004; Sharma, Chrisman \& Chua, 1997) because the absence of a thorough succession plan enhances the risk of business failure (Barach, Gantisky, Carson \& Doochin, 1988; Seymour, 1993).

In particular, we aim to answer the following research questions: (1) How can agency theory elucidate the specific benefits and drawbacks associated with trusted advisor involvement along the different phases of a family firm's succession-planning process? and (2) Based on those theoretical deductions, what constellations of the roles and relationships of incumbents, 
successors, and trusted advisors are likely to maximize or minimize agency costs during the succession process? After a brief overview of the extant research on trusted advisors, succession planning, and agency theory in family firms, we focus on how trusted advisors either increase or decrease important agency costs throughout the four phases of the succession-planning process. Subsequently, we discuss four commonly observed constellations of the relationship between incumbents, successors, and trusted advisors and analyze the costs and benefits associated with those constellations. We argue that a constellation with two or more instead of one trusted advisors is not only inefficient, but also increases agency costs. Furthermore, we discuss that lack of bias (i.e. when the trusted advisor does not favor either party) is a crucial prerequisite for agency costs being minimized rather than maximized through advisor involvement in family firms.

Our article contributes to the literature in several ways. First, we advance the research on trusted advisors in family businesses by building on agency theory to systematically investigate the advantages and disadvantages stemming from trusted advisor involvement. Most extant studies on family firm advisors are characterized by a focus on anecdotal evidence and lack of theoretical rigor (see critique by Jaffe \& Lane, 2004; Strike, 2012; Swartz, 1989; Upton, Vinton, Seaman \& Moore, 1993). Second, we further extend the literature on family business succession by systematically integrating the role played by trusted advisors and his or her impact on agency costs. Instead of the dyadic relationship between an incumbent and a successor (Handler, 1994), we move to the triadic relationship between incumbents, successors, and trusted advisors, which alleviates several agency costs but gives rise to other agency costs. Thereby, we focus in particular on agency costs in form of goal divergence and information asymmetry and outline in detail how trusted advisors on the one hand mitigate and on the other hand increase those costs. Third, we discuss several constellations of trusted advisor involvement commonly observed in 
practice - such as relying on advice from several consultants or engaging a close accountant to manage the succession process - and identify their related agency costs. After the identification and an extensive discussion of the positive and negative effects of trusted advisors on agency cost, we synthesize a proposition of a balanced and efficient model that reduces those agency costs. Fourth, we also advance research on agency theory. Although there is a large body of research on agency costs in family businesses, most of this research focuses on classical ownermanager relations. This manuscript extends this predominant view by including the trusted advisor as a further actor that, while neither being owner nor manager of the firm, can affect the level of agency conflicts in the firm. Doing so provides a more nuanced picture of agency costs in family firms that is not restricted to dyadic relationships but considers a triadic relationship.

\section{THEORETICAL BACKGROUND AND KEY CONCEPTS}

\section{The Succession-Planning Process}

Succession in family business is widely seen as the process that transfers ownership and leadership from an incumbent to a next-generation successor, who may or may not be a family member (Sharma, 2004; Steier \& Miller, 2010). Researchers agree that succession is one of the most important processes of a family business's life cycle due to its substantive effect on the firm's strategy, culture, and also its survivability (Ahlers, Hack, \& Kellermanns, 2014; Cater III \& Kidwell, 2014; Handler, 1994). The succession-planning process, which is the focus of this paper, is the first and one of the most important parts of the overall succession process and has two main goals: first, the selection of the successor, which includes setting criteria or defining a pool of possible candidates (Le Breton-Miller et al., 2004); and, second, preparation for the transfer of management control as well as ownership shares from an older to a younger generation (Sharma et al., 2003). Because the planning process embraces every successionrelated activity from the incumbent's first consideration of his or her exit to the actual transfer of 
leadership and ownership, it is determinant of the outcome of the entire succession process and thus, is particularly worthy of study (Chittoor \& Das, 2007; Sharma et al., 1997). Based on an extensive review of prior literature on family firm succession, we synthesize four important phases of the succession planning process: the trigger phase, the preparation phase, the selection phase, and the training phase (Brockhaus, 2004; De Massis et al., 2008, Murray, 2003; Le Breton-Miller et al., 2004). Those phases can differ in length and can either occur consecutive or (partly) in parallel ${ }^{1}$. Table 1 provides an overview of ten important, previously published studies that investigated the succession planning process in detail and links their findings to the four phases applied in this manuscript.

Insert Table 1 around here

The first step in succession planning is an incumbent's readiness to hand over the business, which is often initiated by a trigger (Murray, 2003). The trigger to consider one's own exit from a business can be a result of developmental pressures such as age or health, internal forces such as family, a predestined succession candidate, or company management, or external pressure for a change, for example, from accountants or customers (Gersick, Lansberg, Desjardins \& Dunn, 1999). One important aspect of succession readiness is an incumbent's willingness to hand over the business (Brun de Pontet, Worsch \& Gagne, 2007): While owner-managers of family firms typically possess the general desire to handover the business to their children one day (e.g., Chua, Chrisman \& Sharma, 1999), it is frequently observed that family firm incumbents are characterized by emotional attachment to the firm (Morgan \& Gomez-Mejia, 2014) and by a reluctance to "let go" (Sharma, Chrisman, Pablo \& Chua, 2001). As a consequence, they tend to

\footnotetext{
${ }^{1}$ At times those phases might have unclear starting and ending points, in particular the first phases can even occur rather unconsciously and/or in an unplanned, unsystematic way. As this article focuses on the impact of trusted advisors in each of the four phases, we henceforth assume a conscious and rather defined nature of all four phases.
} 
postpone their decision to withdraw from the business again and again with succession candidates remaining in a prolonged waiting position, known as the "prince Charles syndrome" (Rothwell, 2010).

After succession is initialized in the trigger phase, the preparation of the succession process begins. The first task in this phase is to create an initial vision of how the business should operate in the future, which is shared by the incumbent and — if already available — the succession candidate. Moreover, it is necessary to specify the goals, rules, and guidelines that every involved party must follow during the succession process, and a time plan—including milestones—must be defined (Le Breton-Miller et al., 2004). In family businesses, in which incumbent and successor have already shared a long history, this process is likely less complicated due to a common understanding of the business's identity and needs that has grown over years (Sharma et al., 1997).

The preparation phase of the succession process is followed by the selection phase, which consists of tasks such as defining the pool of candidates, criteria for and rules of selection, and guidelines for the successor's future training. In family firms the selection criteria used by the incumbent are often guided by personal fit as well as family needs and are less driven by profitmaximization as compared to non-family firms (Chua, Chrisman \& Sharma, 2003; Westhead \& Cowling, 1997). During this phase, a communication plan is defined that governs how to share news about the succession to stakeholders such as employees, suppliers, or customers, including timing and who bears responsibility for issuing succession-related communications (Le BretonMiller et al., 2004). ${ }^{2}$

\footnotetext{
${ }^{2}$ Communication of the succession plan involves exchange with various family and non-family stakeholders. As each of them has different needs and goals, setting up a comprehensive communication plan is a rather complex task that might be difficult to perform. However, as this manuscript focuses on the relationships of incumbent, successor, and trusted advisor, the specifics of such communication are out of the scope of this manuscript.
} 
After a successor has been chosen, the succession process enters the training phase, in which he or she is trained and prepared for his or her new role. Family firms typically take an approach to training that is more personal and relationship-oriented compared to that of nonfamily firms, which prefer a more formalized, task-oriented approach (Fiegner, Brown, Prince \& File, 1994). Therefore, in a family business commitment to the business and to the quality of the incumbent-successor relationship are important because those commitments have a positive effect on succession planning and successor training (Lansberg \& Astrachan, 1994; Seymour, 1993).

\section{The Role of Trusted Advisors in Family Firms}

The literature on trusted advisors in family businesses distinguishes among three types of advisors: formal advisors (many of whom are trusted advisors), informal advisors, and familyfirm boards (Strike, 2012). Formal advisors are hired by the family or the firm and hold either an external or an internal position. They can be content experts-i.e., specialists within a specific area such as financing, law, tax, investments, or products - or they can be process-oriented consultants who focus on developing the firm or implementing new structures. In principle, both types of advisors can serve as trusted advisors. Nevertheless, family firms often seek a trusted advisor that embodies a combination of the two-i.e., a process-oriented consultant with succession-specific knowledge (Strike, 2012). Often, formal advisors are hired only temporarily (Hilburt-Davis \& Senturia, 1995). In contrast to formal advisors, informal advisors are not officially involved in the business. They are highly trusted individuals such as close friends, spouses, other family members, mentors, or business partners, who may support the firm with their advice, support, and empathy (Strike, 2013). As a third type of advisor, the family-firm (advisory) board is frequently mentioned in the literature (Strike, 2012). 
Research has identified several characteristics shared by trusted advisors, in addition to deep content knowledge, which foster the consulting process and increase the likelihood of a positive outcome. Trusted advisors are often characterized by attributes such as honesty, integrity, loyalty, predictability, and empathy (Strike, 2012). In addition, an advisor's goal orientation also positively affects his or her ability to provide innovative advice. It has further been found that compared to advisors with an avoidance orientation, advisors with a high learning orientation are better at taking feedback that reflects the client's needs and combining that feedback with existing information sources to provide innovative, new solutions (Davis et al., 2013). Most trusted advisors help the family in a subtle way, capturing and influencing attention to an issue and then facilitating collective action (Strike, 2013). Therefore, it is important that a trusted advisor is well embedded into the family firm to provide effective advice (Barbera \& Hasso, 2013). Moreover, independence and the willingness to share knowledge and follow a teamwork approach have been shown to increase advisors' efficacy in family firms ( $\mathrm{Su}$ \& Dou, 2013). In the remainder of this paper, we focus on externally hired, trusted advisors because due to their firm- and family-external, independent perspective, they are expected to provide family businesses with specific benefits (Lane et al., 2006).

\section{Agency Theory and Family Businesses}

Agency theory highlights specific conflicts that arise when a (business) owner (i.e., a principal) assigns responsibility to a delegate (i.e., an agent) (Fama \& Jensen, 1983). Conflicts thereby particularly arise due to diverging goals of principal and agent as well as due to an asymmetric distribution of information among them (Eisenhardt, 1989). One of the underlying assumptions of agency theory is that the agent is primarily striving for maximizing his or her own benefit instead of that of the principal, in other words the goals of agent and principal substantially diverge. This goal divergence is exacerbated by the inherently different attitudes toward risk of the principal 
and the agent (Fama \& Jensen, 1983). Besides diverging goals, principals are also challenged with monitoring the behavior of the agent. It is assumed that the principal has inferior knowledge about the actions taken by the agent, while the agent often has less than perfect information on the principal's precise goals and motivation, in other words there is substantial informational asymmetry between the two parties (Eisenhardt, 1989).

Referring to family businesses, researchers have long assumed that family firms have zero or at least insignificant agency costs due to aligned interests of owners and (family) managers in those firms (Jensen \& Meckling, 1976). More recent research, however, has revealed that agency costs are also prevalent in family firms (e.g., Chrisman, Chua \& Litz, 2004), for instance due to nepotism (Schulze, Lubatkin, Dino \& Buchholtz, 2001) or expropriation of minority shareholders (Cronqvist \& Nilsson, 2003; Arosa, Iturralde \& Maseda, 2010).

Within the last years, scholarly interest in the agency costs associated with family firm succession has grown (Aguilera \& Crespi-Cladera, 2012; Chrisman, Chua, Steier, Wright \& McKee, 2012; Pieper, 2010). Divergent goals and interests among the involved parties arise, for example, if the incumbent strives for continuity of the firm and the preservation of traditions, whereas the successor seeks sometimes-radical ways to distinguish him- or herself (Brun de Pontet et al., 2007). Additionally, informational asymmetries exist among incumbent and successor. On the one hand the incumbent is expected to possess much deeper knowledge about the firm, its performance, strengths and weaknesses than the successor. On the other hand the successor has superior knowledge about his or her own abilities and about the plans he or she has with the business post-succession (Dehlen et al., 2014).

The involvement of an external advisor, adds an additional agent with own goals and a specific set of information to the process. Following the underlying assumptions of agency theory, the advisor can be expected to strive for maximizing his or her own benefit. At the same 
time, the trusted advisor possesses specific expert knowledge, experience, and skills to contribute to mitigating agency costs.

\section{TRUSTED ADVISORS IN THE FAMILY BUSINESS SUCCESSION-PLANNING PROCESS: A CONCEPTUAL MODEL}

In the following section, we will analyze in detail how trusted advisors can enhance and/or mitigate agency costs, in particular information asymmetries and goal divergence among involved parties, in each of the four phases of succession planning. The results of this analysis are summarized in Table 2.

Insert Table 2 around here

The Trigger Phase. The trigger phase (Murray, 2003), often also called pre-succession phase (Nordqvist, Wennberg \& Hellerstedt, 2013), is the first phase in the succession planning process. Often, in this phase, the attention of the incumbent as well as of, for instance, family members and potential succession candidates (if already available) is drawn for the first time on the concrete steps associated with succession. The major challenges in this phase are (1) that the incumbent must become aware of the need for succession in the near (as opposed to the far) future, (2) that the incumbent needs to build up his or her willingness to withdraw and prepare both the business and the family for succession, and (3) that the succession process must be initiated (Brun de Pontet et al., 2007; Murray, 2003). In this context, the incumbent often lacks the experience and ideas to cope with the common initial feelings of resistance to letting go (Hilburt-Davis \& Senturia, 1995). Moreover, he or she is often doubtful of finding a successor with sufficient leadership and governance skills as well as commitment to the business (Brun de Pontet et al., 2007; Cabrera-Suarez et al., 2001). 
The incumbent's reluctance to let go and his or her often vague and unspecific fears about the future often imply goals that diverge from those of his or her family members and the successor candidate (if already available). In particular, the involved parties often disagree regarding the following topics (e.g., Brun de Pontet et al., 2007): when to start the procedure (incumbents often vote for a postponed initialization), how to process the succession (incumbents often do not see the need for formalized evaluation of what they believe is a healthy and wellperforming business), and when to handover ownership and leadership (incumbents often prefer longer timespans until the official succession). Moreover, this initial phase is also challenged by information asymmetries between the incumbent on the one hand and the family and the successor candidate on the other hand: In particular, the latter do not possess full information on the incumbent's real intentions to step back and whether and how to execute the succession process because many incumbents prefer not to communicate their intentions in a clear way or tend to keep changing their minds due to their intense feelings of uncertainty (Hilburt-Davis \& Senturia, 1995). Principal-principal conflicts—a long overlooked form of agency problems (Young, Peng, Ahlstrom, Bruton \& Jiang, 2008) — between the incumbent (i.e. current principal) and the successor candidate (i.e. future principal) as well as family members (often possessing some shares of the firm and thus also principals) are the result of such uneven distribution of information and divergence of interests.

Advisors can alleviate those principal-principal problems by adopting the role of a neutral, external mediator who facilitates discussions among the incumbent, the successor candidate (if available), and family members. In particular, based on previous experience with succession cases and interpersonal skills, he or she can promote the communication among all involved parties and thereby reduce informational asymmetries. Moreover, due to their education, training, and experience, advisors can provide important and objective information on the succession 
process, especially they can point out when a specific change is needed and the succession process has to be started (Lane et al., 2006; Swartz, 1989; Upton et al., 1993) due to objectively assessable criteria such as age or health of the incumbent (Cadieux, Lorrain \& Hugron, 2002; DeTienne, 2010; Dyer \& Handler, 1994). Additionally, advisors can help the incumbents dispose of their vague human fears regarding the unknown future of the firm and themselves: Advisors do so by providing comprehensive information on potential exit choices as well as the specifics of the succession process and by closely coaching the incumbent—measures that help the incumbent to get ready for the succession and overcome the reluctance to step aside (Brun de Pontet et al., 2007; De Massis et al., 2008; Salvato \& Corbetta, 2013; Strike, 2012) and thereby align the goals of the incumbent with those of other family members as well as the potential successor candidate.

However, the involvement of an advisor can also imply agency costs between the incumbent (i.e. principal) and the advisor (i.e. agent) if the advisor's own goals are not aligned with those of the other involved parties and/or if communication does not flow smoothly among the involved actors. Concerning the goal alignment in the trigger phase, advisors typically aim for a timely official start of the succession process for the purpose of generating revenues, whereas incumbents typically show an initial reluctance to step aside. More specifically, an advisor who lacks the required sensitivity likely enforces the incumbent and his or her family to consider succession, even if they are not ready to engage in such a process (Hilburt-Davis \& Senturia, 1995). The incumbent and his or her intimates, in turn, likely react with an even increased level of reluctance to engage in the succession-planning process. Thus, to avoid such increased conflicts based on diverging goals, the advisor must first gain at least tacit approval by the incumbent before starting the succession process (Lane, 1989), otherwise, the incumbent's reaction to the advisor's succession-related suggestions can be negative or even hostile (Upton et 
al., 1993). Such issues are especially salient if the advisor has been hired for instance by the successor candidate rather than by the incumbent him- or herself (Lane, 1989).

Moreover, the involvement of a trusted advisor can also further disturb the information flow and result in increased informational asymmetries: In particular if the advisor over-identifies with one party, for instance because of a long-lasting and trusted relationship, the advisor's suggestions become less neutral and his or her expert and process knowledge (Hilburt-Davis \& Senturia, 1995) is less evenly distributed among the involved parties. As a consequence, the communication among the incumbent, family members, and the succession candidate (if available) becomes less open, which, in turn, further reinforces the asymmetrical character of available information on the succession process. The presence of an outside individual (i.e. the advisor), and simultaneous lack of open communication, likely increases the uninformed parties' reluctance to follow the advisor's recommendations and increases conflicts among all involved individuals.

In case such goal divergence and informational asymmetries are present, the advisor will not work on solutions that best match the firm and its owner, thus resulting in classical principalagency conflicts with the advisor (i.e. the agent) providing recommendations that do not fit the incumbent (i.e. the principal). The likely outcome of such principal-agent conflicts is the reluctance of the incumbent to further continue the succession process which leads to our first two propositions:

Proposition 1: In the trigger phase, trusted advisors can mitigate principal-principal conflicts by drawing attention to succession, supporting the incumbent in coping with reluctances, officially starting the process, and proactively communicating with all involved stakeholders. Thereby advisors reduce information asymmetry and improve the goal alliance.

Proposition 2: However, if the goals of an incumbent and advisor are not aligned in the trigger phase, then the involvement of a trusted advisor likely forces the incumbent into decisions for which he or she is not yet ready, ultimately provoking the incumbent's reluctance and leading to 
a hostile reaction from all involved parties. In this case, problems of goal divergence and information asymmetry are even increased leading to increased agency costs.

The Preparation Phase. Tasks belonging to the preparation phase of the succession planning process include especially agreement on strategic, financial, and timing related aspects. A careful preparation of such aspects is crucial in order to ensure the continuity of the business as well as family harmony (Le Breton-Miller et al., 2004). Often, major challenges occur within this phase because expert knowledge in areas such as tax and law or process knowledge is required (Kaye \& Hamilton, 2004; Strike, 2012; Upton et al., 1993)—knowledge which incumbents, the potentially available successor candidates, and their respective firms often do not possess.

We argue that within this phase, problems of information asymmetry, particularly due to a lack of process and task knowledge, and problems of divergent goals between the incumbent and other stakeholders such as family members and the potential successor candidate are prevalent leading to principal-principal agency costs. As members of family businesses often lack experience of how to set up the succession process and lack knowledge which tasks have to be fulfilled and at what time, a clear process plan with defined tasks and a proper documentation of the progress is often missing. As a consequence, information about what is going on and why, as well as about agreed next steps, is not equally distributed among the involved actors, leading to severe informational asymmetries. Reasons why goal divergence arises are similar to what has been discussed for the trigger phase: Family members and/or the potential successor candidate likely aim for a rather quick succession planning with milestones coming quickly after each other, whereas the incumbent wants to take substantial time finding the "ideal successor." As a consequence of such informational asymmetries and simultaneous goal divergence, the principalprincipal conflicts between the incumbent, the family members, and the successor candidate (if 
available) as described in the trigger phase are continued and even enhanced in the preparation phase.

Trusted advisors can again mitigate those agency problems, in particular through their experience with similar cases and their deep content and process knowledge. First, due to their training and knowledge in "succession planning" and "strategic management," advisors can contribute to improve the preparation phase by helping the stakeholders defining a vision, goals, and guidelines for the succession process, which contributes to alleviating concerns regarding the other parties' intentions and to aligning goals of all involved individuals. Additionally, based on their prior experience with similar cases, advisors can organize a task group where each member has a specific role and establish a clear timeline including the definition of milestones (Chrisman, Chua, Sharma \& Yoder, 2009; Le Breton-Miller et al., 2004; Morris, Williams, Allen \& Avila, 1997). Such actions reduce uncertainty among the participants and thus reduce the risk of conflicts based on ignorance or misinterpretation. Second, in order to avoid further conflicts based on diverging goals the trusted advisor can also mitigate conflicts between the incumbent, the family, and the successor candidate through shifting the focus from emotional issues to a more objective and rational perspective that focuses on the process and its various tasks (Upton et al., 1993), thereby adopting the role of a neutral, arbitrating outsider. Third, advisors can provide additional expert knowledge for example concerning procedural or financial aspects (Gedajlovic, Carney, Chrisman \& Kellermanns, 2012; Hilburt-Davis \& Senturia, 1995; Ward, 1997). In doing so trusted advisors reduce again informational asymmetries among the involved parties and thus reduce the risk of conflicts among the principals. In case the advisors lack required specific knowledge or skills to improve the information level, they are typically able to draw on resources from their professional network. In sum, the involvement of trusted advisor increases the goal alliance between incumbent, family members, and the successor candidate and reduces 
information asymmetry through provision of process and task knowledge leading to an overall reduction of principal-principal conflicts.

However, bringing in an external advisor during the preparation phase also leads to further agency costs, which subsequently decrease the possibility of a positive outcome of the preparation phase. We argue that information asymmetry and goal divergence are reinforced for two reasons. First, CEOs typically tend to focus on the strengths of their firms (Poza, Hanlon \& Kishida, 2004) and assess their businesses' fitness for succession more favorably than other individuals with more objective, outsider perspectives. In particular trusted advisors, due to their experience with business transfers and their independent, external perspectives, adopt a more critical perspective of the firm's strengths. In order to sustain their internal belief system ("confirmation bias"), incumbents are inclined to hide important information about the firm's strengths, weaknesses, and outlook from the advisor. However, advisors who have incomplete information are unable to provide well-tailored support to a firm and its stakeholders. We thus argue that in the likely case of information asymmetry between incumbent and advisor, the advisor's recommendations are not well grounded in firm specifics, neglect important aspects, and eventually are of limited benefit to the overall succession process.

Moreover, the preparation phase can be further complicated by goal divergence between the advisor (on one side) and the incumbent, the succession candidate, and family stakeholders (on the other side). Advisors with deep expert knowledge are often inclined to focus too closely on expertise issues and neglect the idiosyncratic firm characteristics as well as emotional aspects that are particularly important to family stakeholders (Goodman, 1998; Kaye, 1996). A trusted advisor's focus on textbook solutions and his or her own goals, rather than adjusting his or her advice to the specific needs of the family business entails further goal conflicts. This divergence of goals increases the resistance of the involved parties to further cooperate with the advisor and 
can ultimately result in the delay or termination of the succession process. Thus goal divergence and information asymmetry lead to agency conflicts, in which the agent (i.e. the advisor) provides inferior suggestions regarding for instance strategic and financial aspects to the principal (i.e. the incumbent), in case the informational flow from the incumbent to the advisor is insufficient and in case the advisor is focused on his or her own goals. In summary, we propose as follows: Proposition 3: In the preparation phase, trusted advisors can mitigate principal-principal conflicts by providing process and task knowledge, clearly defining rules, guidelines and a timeline as well as mitigating conflicts. Thereby advisors improve the goal alliance and reduce information asymmetry.

Proposition 4: However, if an incumbent and an advisor in the preparation phase do not fully share information (for example, because the incumbent is suppressing facts) or if a divergence of goals occurs (for example, due to neglected emotions), then the involvement of a trusted advisor likely leads to inappropriate recommendations to and resistance by the involved parties that increase problems of goal divergence and information asymmetry and ultimately agency costs.

The Selection Phase. After the preparation phase, the selection of the successor takes place (Chittoor \& Das, 2007; Harveston, Davis \& Lyden, 1997; Le Breton-Miller et al., 2004). Within this phase, a pool of possible internal and/or external candidates as well as the ultimate selection criteria for a successor is defined. Subsequently, one has to assess the fit of the identified succession candidate(s) with the business strategy as well as the competitive environment, and finally agree on a succession option which fits best with the incumbent, the firm, and the family (Brockhaus, 2004; Le Breton-Miller et al., 2004).

The major challenges of this phase for the family business are again related to goal divergence and information asymmetry. In this period important discussions need to take place among the affected stakeholders about the successor selection as well as details on the business transfer (Le Breton-Miller et al., 2004). Often those discussions are conflict-laden and highly emotional, since each involved party has idiosyncratic interests. Most importantly, the preferences regarding the successor frequently diverge. While the designated succession candidate wants to ensure that he or she is chosen as successor, family members might wish for a 
candidate willing to pay a high sales price in order to ease the family's financial situation. The incumbent's preference can depend on various factors such as sympathy with a candidate or perceived fit with the firm's culture and strategy. Further typical controversial subjects in this regard are again the preferred time schedules, but also the perceived fair sales price (if applicable), and the desired level of post-succession strategic change. To strengthen their own positions during negotiations, each actor is incentivized to hide information-e.g., facts about the firm's value or post-succession plans - from each other (Dehlen et al., 2014), which ultimately leads to an asymmetric distribution of information and to severe conflicts among the involved principals.

A trusted advisor can reduce such principal-principal agency conflicts and contribute to the positive outcome of the selection phase by assuming a mediating role that aims to resolve goal conflicts, and by fostering an efficient information flow between incumbent and successor candidates, which reduces information asymmetries. In other words, trusted advisors firstly mitigate problems of goal divergence by providing support in defining (and agreeing on) objective selection criteria, and by helping the parties to concur in the successor selection. When it comes to defining the pool of potential succession candidates, advisors can provide valuable input based on their access to their external professional network and thus enlarge the pool of potential candidates (Strike, 2012). Thereby advisors provide more options and thus increase the probability that one candidate fulfills the interests of all involved parties. Moreover, trusted advisors reduce information asymmetries by providing objective outsider information to the conflict-laden discussions among the incumbent, the family members, and the successor candidates and by stimulating the exchange of information in such discussions (Lane et al., 2006). 
However, besides this mitigating effect on agency conflicts, trusted advisors can also lead to increased agency conflicts resulting in an inferior outcome of the selection phase. First, as noted above, all involved parties — the incumbent as well as other family members—-might have some subconscious preference for (or reluctance against) one or more of the available successors based on, for instance, sympathy or family ties. Moreover, firm specifics such as organizational culture frequently require a specific type of successor. This type of information, however, often remains tacit and is not communicated to the advisor (Upton et al., 1993). As a consequence of such informational asymmetries, the advisor will base his or her recommendation on mostly rational selection criteria and neglect the tacit preferences and needs of family members and the firm $^{3}$ (Hilburt-Davis \& Senturia, 1995). Thus, the successor proposed by the advisor is likely well-qualified, however, that successor is not necessarily a suitable successor for the long run due to neglected firm specifics as well as family preferences (Le Breton-Miller et al., 2004; Upton et al., 1993). In such case the recommendations provided by the advisor (i.e. the agent) regarding to whom to transfer ownership and leadership of the firm do not match the vision of the incumbent (i.e. the principal).

Second, the incumbent and the chosen successor often have divergent goals, in particular with respect to the timing of the transfer of ownership and leadership (Brun de Pontet et al., 2007), the sales price and financing (if applicable), and the firm's future strategic focus. Such principal-principal conflicts are exacerbated by the involvement of an advisor if he or she is not able to adopt a neutral position and moderate the conflicts among the current and future principal. This is for instance the case if the advisor lacks the experience and sensitivity related to how to conciliate such emotion-laden situations, or if that advisor either follows his or her own agenda, or lacks crucial information. Similar to the previous phases, the involvement of an advisor can

\footnotetext{
${ }^{3}$ A similar outcome is expected if the criteria are communicated to the advisor but neglected by him or her, for instance due to insensitivity or a lack of experience.
} 
impede the selection phase if one or more of the individuals involved do not accept his or her intervention. This is expected to result in feelings of offense and reluctance and in the worst-case scenario can lead to severe conflicts between incumbents and successors (Herz Brown, 1998; Kaye, 1996). Our outlining in connection with the selection phase leads to the following propositions:

Proposition 5: In the selection phase, trusted advisors can mitigate principal-principal conflicts by supporting the incumbent and family in defining clear selection criteria, by enlarging the pool of possible successor candidates, by mitigating conflict-laden discussions, and ensuring the equal share of information among all involved actors. Thereby advisors improve the goal alliance and reduce information asymmetry.

Proposition 6: However, if incumbents, successors, and trusted advisors do not fully share information about firm specifics during the selection phase (for example due to neglected facts by the advisor) or the advisor's intervention is not accepted (for example, due to the advisor and the other involved parties' divergent goals), then the involvement of a trusted advisor likely leads to the choice of an inappropriate successor, feelings of offense, reluctance, or even severe conflicts among the involved parties what even increases problems of goal divergence and information asymmetry and thus agency costs.

The Training Phase. After having agreed on a successor, the successor-training phase begins (Le Breton-Miller et al., 2004). The overall aim of this phase is for the successor to acquire necessary governance, leadership, and business-related skills and to gain acceptance and trust from all involved parties (Cabrera-Suarez et al., 2001; Fiegner et al., 1994; Le Breton-Miller et al., 2004). A major task in this phase is that the successor gets in contact with all relevant stakeholders within and outside of the firm, such as employees, customers, and suppliers. The successor must fully understand the business, including its strengths and weaknesses, and must gain knowledge about how its internal processes work to identify promising opportunities and to further develop the business (Brockhaus, 2004; Goldberg, 1996).

Agency conflicts among principals arise in this phase, in case there is no pre-defined, institutional training for the successor available and in case there is disagreement between the incumbent and the successor about what type of training is appropriate and in which areas the 
successor lacks ability and experience (Miller, Steier \& LeBreton-Miller, 2003). In order to make sure that the business is transferred to a most capable candidate (Dehlen et al., 2014) the incumbent typically prefers a long training phase, whereas the successor, due to his or her goal of taking over full responsibility as soon as possible, strives to minimize the training phase. As a consequence, the successor is incentivized to hide his or her true level of ability from the incumbent and, in turn, the incumbent does not provide all the knowledge the successor would need to successfully lead and govern the firm. Through this hiding of crucial information from both parties, informational asymmetry is increased, often resulting in insufficient training of the successor and, as a consequence, leading to inferior capabilities of the new firm owner-manager. In this phase, well-equipped and skilled trusted advisors generate compromise solutions in cases of diverging goals regarding the scope and intensity of the training and decrease the informational asymmetries between the two parties regarding the successor's capabilities as well as requirements to lead and govern the firm. In particular, trusted advisors mitigate problems of information asymmetry between incumbent and successor by objectively evaluating the successor's abilities, by closely coaching the successor, and by moderating possible conflicts between the two actors (Brun de Pontet et al., 2007; Lane, 1989). During this phase, trusted advisors often set up a detailed training plan for the successor including firm internal training, which ensures the successor's involvement into all business areas, as well as appropriate external training possibilities (Miller et al., 2003). Such a detailed plan, created by a well-informed but neutral individual is most likely to match with the goals of both, incumbent and successor, and to be accepted by both parties.

However, involved advisors can also lead to increased agency costs in the training phase because advisors often reduce the successors' independence through excessively tight coaching, and, in extreme cases, even edge them out of their jobs (Lane, 1989). Such behavior is the result 
of an advisor primarily following his or her own goals and aiming to give evidence of his or her own leadership skills (Hilburt-Davis \& Senturia, 1995). Increased independence and lack of managerial discretion of the successor, however, can also occur if the incumbent lacks trust in the successor's capabilities (Brun de Pontet et al., 2007) and subsequently mandates the advisor to enforce an extended training, coaching, and supervising program. Another root cause of overly tight training and a lack of responsibility handover is severe informational asymmetries, for instance, if the successor is not willing to disclose his or her real capabilities in presence of an external agent, the advisor.

The outcome of such inappropriate measures within the training phase is that the successor is poorly prepared for his or her role as owner-manager of the firm and, in some cases, is even edged off from the leadership role because of a lack of discretion and a subsequent lack of trust from other stakeholders. In other words, the actions of an agent (i.e. the advisor) in such case are counterproductive to the goals of the principals, leading to increased agency costs, thus we summarize:

Proposition 7: In the training phase, trusted advisors can mitigate principal-principal conflicts by providing accurate training for the successor, ensuring the successor's involvement into the business, assessing the successor's abilities, coaching the successor, and by mitigating conflicts between incumbent and successor concerning the training. Thereby advisors improve the goal alliance and reduce information asymmetry.

Proposition 8: However, if the goals of the incumbent, successor, and trusted advisor in the training phase are not aligned (for example, due to different opinions about appropriate training methods or to the presence of a dominant advisor with his or her own leadership ambitions), then the involvement of a trusted advisor likely leads to the successor receiving inefficient training or even failing through which problems of goal divergence and information asymmetry and consequently also agency costs are increased.

\section{The Triadic Relationship of Incumbent, Successor, and Trusted Advisor: Bias and Efficiency}

Traditionally, the family business research has referred to the incumbent and the successor as the primary actors in the succession-planning process and has analyzed their relationship and related 
agency costs, particularly in the forms of information asymmetry and divergent goals (Handler, 1994; Howorth, Westhead \& Wright, 2004; Le Breton-Miller et al., 2004; Sharma et al., 1997). In our conceptual article, we integrate the trusted advisor as an individual that can mitigate but also create agency costs into the succession-planning process. Thus, we extend the dyadic incumbentsuccessor relationship to a triadic relationship among incumbent, successor, and trusted advisor.

In the previous sections, we discuss the potential contributions of trusted advisor involvement based on their ability to decrease principal-principal agency costs arising out of information asymmetry and divergent goals between incumbent and successor. Below, we examine four different, commonly observed, constellations of the relationship among incumbents, successors, and trusted advisors, and discuss under what conditions their benefits and costs are most salient.

Balanced and efficient setup of the triadic relationship. We argue that in order to harvest the benefits of a trusted advisor's involvement, the advisor needs to act as steward of both, the incumbent as well as the successor. In such a constellation, which we label simultaneously balanced and efficient (see Figure 1a), the trusted advisor seeks to generate a continuous flow of information that distributes outside as well as inside information equally to the incumbent and the successor. The advisor acts as facilitator rather than gate-keeper of knowledge. Moreover, the advisor puts his or her own interests into the back and strives to balance the needs of the incumbent and the successor, thereby maximizing the cumulate utility function of all involved parties and minimizing goal divergence through mediation. In such a constellation, the principalagent conflicts associated with advisor involvement (P1-4) are minimized, whereas the alleviating effect of advisor involvement on the principal-principal agency conflicts (P1-4) is maximized. We thus summarize: 
Proposition 9: The presence of one unbiased and balanced advisor who provides equal knowledge to the incumbent and the successor, and who keeps both parties goals' in mind, minimizes agency costs in a triadic setup of incumbent, successor, and advisor and therefore results in a more efficient, smoother and satisfying succession-planning process.

Biased and inefficient setups of the triadic relationship. We continue to argue that trusted advisors increase rather than decrease extant agency costs if the advisor is biased toward either the incumbent (see Figure 1b) or the successor (see Figure 1c).

The first situation (Figure 1b) visualizes a bias of the advisor towards the incumbent. In other words the advisor works as the incumbent's steward, directing informational flows more towards the incumbent and less towards the successor. As a consequence, informational flows among the involved parties are hampered and the successor feels less informed and maybe even neglected. Mistrust of the successor towards the incumbent as well as the advisor can emerge from such a setup. Moreover, working as the incumbent's steward, the advisor is unlikely to strive for goal divergence, instead he or she will aim to maximize the favored party's benefits, for instance by aligning timing, financial, or strategic decisions to the incumbent's interest. Again, such perspective taking of the advisor, will raise dissatisfaction and resentment of the successor and ultimately exacerbate agency conflicts between the current and the future principal.

Such a bias towards the incumbent can arise as the result of having a backward-looking advisor. This is, for instance, the case if there has been a long lasting and close business relationship between the incumbent and his or her trusted advisor, for instance, an accountant (Strike, 2012) but also a banker, lawyer, psychologist, or management consultant. In such a case, the trusted advisor has often served the incumbent for many years, for instance as a financial consultant. Often, in such cases, the trusted advisor is paid by the incumbent (not the firm or the successor), leading to financial interdependencies. Moreover, the emotional aspect of sharing a joint history with various common experiences — which may also include the experience of 
difficult times - strongly connects the two individuals. Furthermore, especially if the trusted advisor has accompanied the incumbent for many years, the two individuals are likely to be of roughly the same age and are expected to share several important values and beliefs, which (partially unconsciously) leads to a better understanding in general. We conclude that in the case of a backward-looking trusted advisor, the advisor is likely to be biased towards the incumbent. We thus summarize:

Proposition 10: If a trusted advisor is biased towards the incumbent (e.g., due to a long-lasting professional relationship, shared memories, and/or age similarities with the incumbent), the trusted advisor no longer reduces information asymmetries and goal divergence among incumbent and successor, but instead increases those problems, leading to high levels of mistrust and principal-principal conflicts.

In the second constellation (Figure 1c), the advisor acts as the steward of the future principal, i.e. the successor. In this case, the trusted advisor is fully aligned with the successor, but not with the incumbent. Consequently, the flow of information is disturbed because information and knowledge are primarily shared between the trusted advisor and the successor. Thus, the neglected party (i.e. the incumbent) is expected to lose faith in the trusted advisor and become reluctant to heed his or her suggestions (Boyd, Upton \& Wircenski, 1999). In sum, in this constellation, the trusted advisor does not contribute to a smooth information flow and does not provide important pieces of knowledge and advice that are accepted by all involved stakeholders. Moreover, the advisor is unlikely to arbitrate and aim for goal divergence, yet he or she takes the perspective of the successor and aims to maximize his or her benefits. Thus, we argue that in this situation, the trusted advisor exacerbates existing principal-principal conflicts between the incumbent and the successor.

Such a bias towards the successor arises if a purely forward-looking individual serves as trusted advisor. In this case, the trusted advisor focuses on the future of the business and, thus, is more likely to be aligned with the successor than with the incumbent. We argue that three root 
causes entail such a constellation. First, this constellation can occur when the advisor sees an urgent need for a change in business strategy. This occurs, for example, if the business is in financial trouble and a complete change in management is necessary to achieve a successful turnaround. Because age often entails inertia, the trusted advisor probably feels the need to pin his or her hopes on the successor. Second, this constellation can occur when the trusted advisor perceives the successor as potential future employer. In this case, the trusted advisor foresees the opportunity to build a long-lasting professional relationship with the successor and earn a salary, whereas the incumbent will soon retire and thus is unlikely to generate future revenues for the advisor. Third, this constellation can occur when the trusted advisor's age is closer to that of the successor. In such a case, the advisor and the successor will most likely have a general better understanding, resulting in a preference (perhaps even unconsciously) for the successor's interests. Because of this constellation, the trusted advisor is likely to be biased towards the successor, thereby neglecting the incumbent's demands and needs. We summarize our arguments in the following proposition:

Proposition 11: If a trusted advisor is biased towards the successor (e.g., due to a need for radical organizational change, due to a perceived opportunity for a future mandate, and/or due to age similarities with the successor), the trusted advisor no longer reduces information asymmetries and goal divergence among incumbent and successor, but instead increases those problems and contributes to high levels of mistrust and principal-principal conflicts.

A fourth often-applied form of trusted advisor involvement occurs when an incumbent and a successor both rely on their own trusted advisor (or team of advisors), whom each often have already known for years (see Figure 1d). This leads to a balanced and robust setup because both parties_-incumbent and successor — enjoy an equal level of trusted-advisor support, and each party's trusted advisor acts in favor of his or her particular client and provides knowledge and advice to that side of the transaction. Through this equal distribution of support, the model gains balance and robustness towards bias. Each trusted advisor clearly represents and is committed to 
only one client, who pays his or her fees. Accordingly, it is unlikely that this setup is biased in favor of one side.

However, we argue that this setup comes at substantial cost, much of them rooted in exacerbated principal-principal conflicts among the incumbent, the successor, and other involved family members. While dedicated advisors facilitate the information flow from outside sources to the advised party (e.g., knowledge how to properly set up a succession process), they likely impede the information flow from one involved party to another (e.g., sharing the incumbent's knowledge about the firm's health with the successor), since the advisors are incentivized to work for their client's benefit rather than maximizing the utility function of all involved parties. Information asymmetries between incumbent and successor are thus even increased in such a setup. Following a similar argumentation, due to the symmetric setup of such a constellation, none of the involved agents (i.e. advisors) will assess it as his or her duty to arbitrate among the involved parties leaving the problems associated with goal divergence unsolved. As a consequence, the majority of the above discussed advantages of an advisor involvement (see Propositions 1-4) are annihilated in such constellation with exacerbated principal-principal conflicts as well as potential principal-agent conflicts threatening the overall outcome of the succession planning process.

Besides agency costs, also direct costs are increased for such constellations of advisor involvement: With an increasing number of advisors involved, the costs of fees and salaries increase - a consequence that can be particularly detrimental for smaller family firms that have limited financial resources (Upton et al., 1993). Moreover, the succession-planning process in such cases is challenged by the fact that with two coequal advisors, there is no ultimate responsible for managing and coordinating the process. With two or even more advisors, there are several, potentially diverging, opinions about how to manage the process in addition to those 
of the incumbent and successor; consequently, agreeing on next steps can become complicated. Even more complex solutions - such as those involving a third advisor or a third team of advisors managing the process - further increase costs, decrease decision-making speed, and increase the likelihood of informational asymmetry. Therefore, due to the further drawbacks and increased complexity that entail inefficiency, we conclude that smaller firms in particular gain from involving just one trusted advisor, not two or more consultants, in leading the process (HilburtDavis \& Senturia, 1995; Upton et al., 1993). The aspects discussed above lead to our final proposition:

Proposition 12: If there are two or more trusted advisors involved, the presences of those advisors reinforces the existing informational asymmetries and diverging goals among incumbent and successor and hence leads to overall higher agency and direct costs. The resulting constellation can be labeled as "robust yet inefficient."

Insert Figure 1 around here

\section{DISCUSSION}

Although there is a huge body of literature on the succession process in family businesses (e.g., Sharma, 2004; Sharma et al., 2012), the role of trusted advisors in this process is still understudied. This is surprising, given the important role of those individuals. Building on the emerging stream of research on family business consultants (Strike, 2012), our goal is to systematically analyze the role of trusted advisors during the four important steps of the succession-planning process. Our analysis is inspired by the ideas of Chua et al. (2003) and Howorth et al. (2004), which link the influence of non-family managers to agency costs such as divergent interests and informational asymmetries (Eisenhardt, 1989; Fama \& Jensen, 1983) and on Chrisman at al. (2012), who study agency costs for specific types of MBOs. In addition, we contrast potential benefits of advisors involvement with the potential costs of advisor involvement (e.g., Hilburt-Davis \& Senturia, 1995; Kaye, 1996; Lane, 1989; Upton et al., 1993). 
In particular, we emphasize that agency costs (Eisenhardt, 1989) among all three parties of the triadic relationship can be on the one hand reduced and on the other hand enhanced in the presence of an advisor especially if those cost are not managed well. Our step-by-step analysis of the effect of trusted advisors on succession-planning-process outcomes thus reveals the doubleedged nature of trusted advisor involvement which can both, increase and decrease agency costs, and contributes to a more balanced and nuanced discussion of the role of family firm advisors (Strike, 2012). Thereby, this article not only contributes to the literature on trusted advisors in family firms but also to the literature agency theory. It shows that the trusted advisor, although he or she is neither owner nor manager of the firm, can substantially alter the relationships between the principals and agents and the firm and thereby influence the level of agency conflicts. As such, this manuscript suggests that the role of potential advisors should be included in further studies analyzing agency costs in organizations. Put differently, it indicates that the simplistic dyadic relationship applied by classic agency studies might be replaced by more complex triadic ones.

Additionally, our article also contributes to the literature on family firm succession (e.g., Gersick et al., 1999; Handler, 1994; Le Breton-Miller et al., 2004; Sharma et al., 2003). Until now, many studies have emphasized the importance of focusing on both parties involved in family firm succession (i.e., the incumbent and the successor), not only one (Handler, 1994). We further extend this literature by including the trusted advisor in the studied relationship. As practical evidence shows, many family firms that undergo a succession process use a trusted advisor in one way or another (Reay et al., 2013). As our analysis shows, trusted advisors can substantially influence the outcome of the succession process-in either a positive or a negative way depending on how well potential agency conflicts are managed. Thus, neglecting the role played by trusted advisors in the family firm succession process potentially leads to overlooking 
important elements of the dynamics of the process and thus, to a distorted understanding of the process.

Moreover, we note the potentially detrimental outcomes caused by a trusted advisor's bias towards one of the involved parties or focus on his or her goals, such as quickly concluding the succession process (Hilburt-Davis \& Senturia, 1995; Howorth et al., 2004; Kaye, 1996; Lane, 1989; Upton et al., 1993), and argue that the optimal setup for trusted advisor involvement is characterized by efficiency (i.e., only one instead of multiple trusted advisors) and lack of bias (i.e., the trusted advisor considers the needs of the incumbent and the successor equally) because in such cases agency costs are particularly low. Finally, we aim to identify the conditions that allow a trusted advisor to achieve a good balance between the incumbent and the successor (i.e., the situation displayed in Figure 1a). Only when the trusted advisor is not only experienced and educated but also successfully balances the needs of both parties, does he or she act as a maximally efficient moderator between the incumbent and the successor (Boyd et al., 1999; Hilburt-Davis \& Senturia, 1995; Howorth et al., 2004). In such constellations, the trusted advisor can reduce agency costs, in particular by mitigating information asymmetries among the stakeholders, moderate the parties' divergent goals, and consequently, effectively contribute to the succession-planning process (Chua et al., 2003; Jaffe \& Lane, 2004; Strike, 2013).

Besides the outlined theoretical contributions, these implications are also of great importance for practice because: On the one hand our findings sensitize incumbents and/or successors to the point that the succession process is likely most successful if it is accompanied not only by a highly qualified but also by an unbiased and equally informing advisor. While this is a challenging task, anecdotal evidence shows that such advisors do exist. In order to identify such an advisor, family firms should not rely on reasons of convenience (e.g., taking the extant accountant or lawyer whom the incumbent knows for a long time) but rather consider the 
experience and prior success of the advisor in accompanying family business successions. Anecdotal evidence show, that the more experienced the advisor is the more likely he or she pursues both parties goals and informs them equally. In addition, family firms are advised to scrutinize whether the opinions and beliefs of the selected trusted advisor are compatible with both, the incumbent as well as the advisor. Moreover, when selecting an advisor each party also has to bear the other party in mind and check whether the advisor is able to equally serve both sides. On the other hand our propositions also sensitize advisors to carefully representing the wishes and needs of both parties equally because through this they can increase the probability that both parties stay on board and will work together to a successful outcome of the succession process - an outcome, which will in turn positively influence the advisor's reputation.

\section{LIMITATIONS, FUTURE RESEARCH, AND CONCLUSION}

Within our theorizing, we identify several benefits and costs of trusted advisors during the individual phases of the succession-planning process. We strongly recommend that researchers build on these first conceptual insights and empirically test whether and under what conditions the benefits or costs of trusted advisors are dominant. In conducting such a study, it will be crucial to differentiate among the individual phases of the succession-planning process. As our analyses show, the costs and benefits of trusted advisor involvement differ from phase to phase. In a similar vein, the ultimate effect of trusted advisor involvement might depend on the phases in which he or she is engaged and, as our propositions reveal, also depends on whether one or more advisors are retained. Moreover, we encourage scholars to study the role and impact of various family and non-family stakeholders in this process.

Although we aimed to systematically integrate the extant literature, several aspects of trusted advisor involvement require further research. For instance, we implicitly assume that trusted advisors possess certain knowledge (which both, incumbents and successors, lack) due to 
their experience and education that can lead to a reduction of agency costs. In subsequent research, it might be beneficial to conduct additional studies about the effect of prior experience and education on the trusted advisor's effectiveness. Moreover, our analysis investigates the easiest possible case, in which one incumbent hands over the business to one successor. However, as the literature shows, team CEO efforts are a common phenomenon (Miller, Le Breton-Miller, Minichilli, Corbetta \& Pittino, 2014). This complexity must be integrated into the model of family-firm succession advisors, because informational asymmetries and goal divergence might be even more salient in those cases.

A second implicit assumption in our model is the parties' trust in the advisor (Howorth et al., 2004; Strike, 2013) because only highly trusted advisors have been shown to be effective advisors (Kaye \& Hamilton, 2004). Thus, similar to "education" and "experience", trust among key parties can play an important role and should attract further scholarly attention. However, "trust" cannot be seen as an isolated construct in family-firm succession, as it is closely tied both to the amount of informational asymmetries and to goal alignment.

Furthermore, our model does not include contextual, cultural, and institutional factors. Is a trusted advisor more often involved in a stable economic environment or in a dynamic environment? Do families in certain cultures seek more often for advice than in others? Does a family firm seek advice if it is economically healthy or is the contrary the case? Further theoretical and empirical effort is required to answer these important questions.

In conclusion, firms with trusted advisors seem to engage in more strategic and succession planning than those without (Blumentritt, 2006). However, the involvement of a trusted advisor not only is associated with a large number of potential benefits but also is associated with disadvantages. It is only when the triadic relationship among incumbents, successors, and trusted 
advisors is well managed that the benefits of advisor involvement are likely to outweigh its additional costs.

\section{REFERENCES}

Aguilera, R. V., Crespi-Cladera, R. (2012). Firm family firms: Current debates of corporate governance in family firms. Journal of Family Business Strategy, 3(2), 66-69.

Ahlers, O., Hack, A., Kellermanns, F. W. (2014). "Stepping into the buyers' shoes": Looking at the value of family firms through the eyes of private equity investors. Journal of Family Business Strategy.

Arosa, B., Iturralde, T., Maseda, A. (2010). Outsiders on the board of directors and firm performance: Evidence from Spanish non-listed family firms. Journal of Family Business Strategy, 1(4), 236-245.

Barach, J. A., Gantisky, J., Carson, J. A., Doochin, B. A. (1988). Entry of the next generation: Strategic challenge for Family Business. Journal of Small Business Management, 26.2, 49-56.

Barbera, F., Hasso, T. (2013). Do we need to use an accountant? The sales growth and survival benefits to family SMEs. Family Business Review, 26, 271-292.

Blumentritt, T. (2006). The Relationship between Boards and Planning in Family Businesses. Family Business Review, 19, 65-72.

Boyd, J., Upton, N., Wircenski, M. (1999). Mentoring in Family Firms: A reflective Analysis of Senior Executives’ Perceptions. Family Business Review, 12, 299-309.

Brockhaus, R. H. (2004). Family Business Succession: Suggestions for Future Research. Family Business Review, 17, 165-177.

Brun de Pontet, S., Worsch, C., Gagne, M., (2007). An Exploration of the Generational Differences in Levels of Control Held among Family Businesses Approaching Succession. Family Business Review, 4, 337-354.

Cabrera-Suarez, K., De Saa-Perez, P., Garcia-Almeida, D. (2001). The succession process from a resource- and knowledge-based view of the family firm. Family Business Review, 14, 37-48.

Cadieux, L., Lorrain, J., Hugron, P. (2002). Succession in Women-Owned Family Businesses: A Case Studie. Family Business Review, 15, 17-30.

Cater III, J. J., Kidwell, R. E. (2013). Function, governance, and trust in successor leadership groups in family firms. Journal of Family Business Strategy 5(3), 217-228.

Chittoor, R., Das, R. (2007). Professionalization of Management and Succession Performance A vital linkage. Family Business Review, 20, 65-79.

Chrisman, J. J., Chua, J. H., Litz, R. A. (2004). Comparing the Agency Costs of Family and NonFamily Firms: Conceptual Issues and Exploratory Evidence. Entrepreneurship Theory and Practice, 28(4), 335-354. 
Chrisman, J. J., Chua, J. H., Sharma, P. (2004). Important attributes of successors in family businesses: An exploratory study. Family business review, 11(1), 19-34.

Chrisman, J. J., Chua, J., Sharma, P., Yoder, T. (2009). Guiding family businesses through the succession process. CPA Journal, 79, 48-51.

Chrisman, J. J., Chua, J. H., Steier, L. P., Wright, M., McKee, D. L. N. (2012). An agency theoretic analysis of value creation through management buy-outs of family firms. Journal of Family Business Strategy, 3(4), 197-206.

Chua, J., Chrisman, J. J., Sharma, P. (2003). Succession and Nonsuccession concerns of Family Firms and Agency Relationship with Nonfamily Managers. Family Business Review, 16, 89-108.

Chua, J., Chrisman, J. J., Sharma, P. (1999). Defining Family Business by Behavior.

Entrepreneurship Theory and Practice, 23, 19-40.

Cronqvist, H., Nilsson, M. (2003). Agency costs of controlling minority shareholders. Journal of Financial and Quantitative analysis, 38(04), 695-719.

Davis, W. D., Dibrell, C., Craig, J. B., Green, J. (2013). The effects of goal orientation and client feedback on the adaptive behaviors of family enterprise advisors. Family Business Review, 26, 215-234.

Dehlen, T., Zellweger, T., Kammerlander, N., Halter, F. (2014). The role of information asymmetry in the choice of entrepreneurial exit routes. Journal of Business Venturing, 29,193209.

De Massis, A., Chua, J. H., Chrisman, J. J. (2008). Factors preventing Intra-Family Succession. Family Business Review, 21, 183-199.

DeTienne, D. R. (2010). Entrepreneurial exit as a critical component of the entrepreneurial process: Theoretical development. Journal of Business Venturing, 25(2), 203-215.

Dyer, W. G., Handler, W. (1994). Entrepreneurship and family business: Exploring the connections. Entrepreneurship Theory and Practice, 19, 71-71.

Eisenhardt, K. M. (1989). Agency theory: an assessment and review. Academy of Management Review, 14, 57-74.

Fama, E. F., Jensen, M. C. (1983). Agency problems and residual claims. Journal of law and Economics, 26, 327-349.

Fiegener, M. K., Brown, B. M., Prince, R. A., File, K. M. (1994). A Comparison of Successor Development in Family and Nonfamily Businesses. Family Business Review, 7, 313-329.

Gedajlovic, E., Carney, M., Chrisman, J. J., Kellermanns, F. W. (2012). The Adolescence of family firm research: taking stock and planning for the future. Journal of Management, 38.4, 1010-1037.

Gersick, K. E., Lansberg, I., Desjardins, M., Dunn, B. (1999). Stages and Transitions: Managing Change in the Family Business. Family Business Review, 12, 287-297.

Goldberg, S. D. (1996). Research Note: effective successors in Family-Owned Businesses: Significant Elements. Family Business Review, 9, 185-197.

Goodman, J. M. (1998). Defining the new Professional: The Family Business Counselor. Family Business Review, 11, 349-354. 
Handler, W. C. (1994). Succession in Family Business: A Review of the Research. Family Business Review, 7, 133-157.

Harveston, P. D., Davis, P. S., Lyden, J. A. (1997). Succession Planning in Family Business: The impact of Owner Gender, Family Business Review, 10, 373-396.

Herz Brown, F. (1998). The "Softer-Side" of Consulting to Business-Owning Families:

Understanding our Clients and Ourselves. Family Business Review, 11, 193-206.

Hilburt- Davis, J., Senturia, P. (1995). Using the Process/Content Framework: Guidelines for the Content Expert. Family Business Review, 8, 189-199.

Howorth, C., Westhead, P., Wright, M. (2004). Buyouts, information asymmetry and the family management dyad. Journal of Business Venturing, 19.4, 509-534.

Jaffe, D. T., Lane, S. H. (2004). Sustaining a family dynasty: Key issues facing complex

multigenerational business- and investment-owing families. Family Business Review, 17, 81-98.

Jensen, M. C., Meckling, W. H. (1976). Theory of the firm: Managerial behavior, agency costs and ownership structure. Journal of financial economics, 3(4), 305-360.

Kaye, K., Hamilton, S. (2004). Roles of Trust in consulting to financial families. Family Business Review, 17, 151-163.

Kaye, K. (1996). When the Family Business is a Sickness. Family Business Review, 9, 347-368.

LaChapelle, K., Barnes, L. B. (1998). The trust catalyst in family-owned businesses. Family

Business Review, 11, 1-17.

Lane, S., Astrachan, J. H., Keyt, A., McMillan, K. (2006). Guidelines for Family Business Boards of Directors. Family Business Review, 19, 147-167.

Lane, S. (1989). An Organizational Development/Team-Building Approach to Consultation with Family Businesses. Family Business Review, 2, 5-16.

Lansberg, I., Astrachan, J. H. (1994). Influence of Family Relationships on Succession Planning and Training: The importance of mediating factors. Family Business Review, 7, 39-59.

Le Breton-Miller, I., Miller, D., Steier, L. P. (2004). Toward an Integrative Model of Effective FOB Succession. Entrepreneurship Theory and Practice, 28, 305-328.

Miller, D., Le Breton-Miller, I., Minichilli, A., Corbetta, G., Pittino, D. (2014). When do NonFamily CEOs Outperform in Family Firms? Agency and Behavioural Agency Perspectives. Journal of Management Studies, forthcoming.

Miller, D., Steier, L. P., Le Breton-Miller I. (2003). Lost in time: intergenerational succession, change, and failure in family business. Journal of Business Venturing, 18, 513-531.

Morgan, T. J., Gomez-Mejia, L. R. (2014). Hooked on a feeling: The affective component of socioemotional wealth in family firms. Journal of Family Business Strategy, 5(3), 280-288.

Morris, M. H., Williams, R. O., Allen, J. A., Avila, R. A. (1997). Correlates of success in family business transitions. Journal of Business Venturing, 12, 385-401.

Murray, B. (2003). The Succession Transition Process: A Longitudinal Perspective. Family Business Review, 16, 17-34. 
Mussolino, D., Calabrò, A. (2014). Paternalistic leadership in family firms: Types and implications for intergenerational succession. Journal of Family Business Strategy, 5(2)197-210.

Nicholson, H., Shepherd, D., Woods, C. (2010). Advising New Zealand's family businesses: Current issues and opportunities. University of Auckland Business Review, 12(1), 1-7.

Nordqvist, M., Wennberg, K., Hellerstedt, K. (2013). An entrepreneurial process perspective on succession in family firms. Small Business Economics, 40(4), 1087-1122.

Pieper, T. M. (2010). Non solus: Toward a psychology of family business. Journal of Family Business Strategy, 1(1), 26-39.

Poza, E. J., Hanlon, S., Kishida, R. (2004). Does the family business interaction factor represent a resource or a cost. Family Business Review, 17, 99-118.

Reay, T., Pearson, A. W., Dyer, W. G. (2013). Advising Family Enterprise: Examining the Role of Family Firm Advisors. Family Business Review, 26, 209-214.

Rothwell, W. J. (2010). Effective succession planning: Ensuring leadership continuity and building talent from within. AMACOM Div American Mgmt Assn.

Salvato, C., Corbetta, G. (2013). Transitional Leadership of Advisors as a Facilitator of Successor's Leadership Construction. Family Business Review, 26, 235-255.

Schulze, W. S., Lubatkin, M. H., Dino, R. N., Buchholtz, A. K. (2001). Agency relationships in family firms: Theory and evidence. Organization science, 12(2), 99-116.

Seymour, K. C. (1993). Intergenerational Relationships in the Family Firm: The Effect on Leadership Succession. Family Business Review, 6, 263-281.

Sharma, P., Chrisman, J. J., Chua, J. H., (1997). Strategic Management of the Family Business: Past Research and Future Challenges. Family Business Review, 10, 1-35.

Sharma, P., Chrisman, J. J., Chua, J. H. (2003). Succession Planning as Planned Behavior: Some Empirical Results. Family Business Review, 16, 1-15.

Sharma, P., Chrisman, J. J., Gersick, K. E. (2012). 25 Years of Family Business Review: Reflections on the Past and Perspectives for the Future. Family Business Review, 25, 5-15.

Sharma, P., Chrisman, J. J., Pablo, A. L., Chua, J. H. (2001). Determinants of initial satisfaction with the succession process in family firms: A conceptual model. Entrepreneurship Theory and Practice, 25(3), 17-36.

Sharma, P. (2004). An Overview of the Field of Family Business Studies: Current Status and Directions for the Future. Family Business Review, 16, 1-36.

Steier, L. P., Miller, D. (2010). Pre-and post-succession governance philosophies in entrepreneurial family firms. Journal of Family Business Strategy, 1(3), 145-154.Strike, V. M. (2012). Advising the Family Firm: Reviewing the Past to Build the Future. Family Business Review, 25, 156-177.

Strike, V. M. (2013). The most trusted advisor and the subtle advice process in family firms. Family Business Review, 26, 293-313.

$\mathrm{Su}$, E., Dou, J. (2013). How does knowledge sharing among advisors from different disciplines affect the quality of the services provided to the family business client? An investigation from the family business advisor's perspective. Family Business Review, 26, 256-270. 
Swartz, S. (1989). The challenges of multidisciplinary consulting to family-owned businesses. Family Business Review, 2, 329-339.

Thomas, J. (2002). Freeing the Shackles of Family Business Ownership. Family Business Review, 15, 321-336.

Upton, N., Vinton, K., Seaman, S., Moore, C. (1993). Research Note: Family business consultants - who we are, what we do and how we do it. Family Business Review, 6, 301-311.

Ward, J. L. (1997). Growing the Family Business: Special Challenges and Best Practices. Family Business Review, 10, 323-337.

Westhead, P., Cowling, M. (1997). Performance contrasts between family and non-family unquoted companies in the UK. International Journal of Entrepreneurial Behaviour \& Research, $3(1), 30-52$.

Young, M. N., Peng, M. W., Ahlstrom, D., Bruton, G. D., Jiang, Y. (2008). Corporate governance in emerging economies: A review of the principal-principal perspective. Journal of Management Studies, 45(1), 196-220. 


\section{TABLES}

Table 1-Overview of Theoretical Papers in connection with the Succession Planning Process

\begin{tabular}{|c|c|c|c|c|}
\hline $\begin{array}{l}\text { Author / } \\
\text { Year }\end{array}$ & Phase 1 & Phase 2 & Phase 3 & Phase 4 \\
\hline This article & $\begin{array}{l}\text { Trigger } \\
\text { Achieving incumbents } \\
\text { awareness and } \\
\text { readiness for } \\
\text { succession }\end{array}$ & $\begin{array}{l}\text { Preparation } \\
\text { Definition of goals, } \\
\text { guidelines and a } \\
\text { timeline for the } \\
\text { succession process }\end{array}$ & $\begin{array}{l}\text { Selection } \\
\text { Definition of selection } \\
\text { criteria, a pool of } \\
\text { possible candidates and } \\
\text { agreement on a } \\
\text { successor }\end{array}$ & $\begin{array}{l}\text { Training } \\
\text { Set-up of appropriate } \\
\text { training for the } \\
\text { successor }\end{array}$ \\
\hline $\begin{array}{l}\text { Brockhaus } \\
(2004)\end{array}$ & $\begin{array}{l}\text { Industry Strategic } \\
\text { Analysis } \\
\text { Answer questions } \\
\text { whether an internal } \\
\text { succession or the } \\
\text { selling of the firm are } \\
\text { better }\end{array}$ & $\begin{array}{l}\text { Family Business } \\
\text { Analysis } \\
\text { Answer questions about } \\
\text { strength and } \\
\text { weaknesses of the } \\
\text { business and what kind } \\
\text { of successor is required }\end{array}$ & $\begin{array}{l}\text { Selection of Successor } \\
\text { Different possibilities } \\
\text { and criteria to select a } \\
\text { successor }\end{array}$ & $\begin{array}{l}\text { Development of the } \\
\text { successor and } \\
\text { Relationship Issues } \\
\text { How to train the } \\
\text { successor, get him or } \\
\text { her exposed to the } \\
\text { business and achieve a } \\
\text { good relationship }\end{array}$ \\
\hline $\begin{array}{l}\text { Brun de } \\
\text { Pontet, } \\
\text { Worsch \& } \\
\text { Gagne } \\
(2007) \\
\end{array}$ & $\begin{array}{l}\text { Ground Rules } \\
\text { Presence of a clear } \\
\text { Successor }\end{array}$ & $\begin{array}{l}\text { Nurturing Successors } \\
\text { Public Progress on } \\
\text { Succession }\end{array}$ & $\begin{array}{l}\text { Selection } \\
\text { Confidence in } \\
\text { successor's leadership } \\
\text { skills }\end{array}$ & $\begin{array}{l}\text { Hand-off / Transition } \\
\text { Get in touch and gain } \\
\text { confidence from other } \\
\text { stakeholders }\end{array}$ \\
\hline $\begin{array}{l}\text { Cabrera- } \\
\text { Suarez, De } \\
\text { Saa-Pérez \& } \\
\text { Garcia- } \\
\text { Almeida } \\
(2001)\end{array}$ & $\begin{array}{l}\text { Predecessor } \\
\text { Motivation } \\
\text { Overcoming of } \\
\text { psychological fears } \\
\text { about succession }\end{array}$ & $\begin{array}{l}\text { Business Context and } \\
\text { Family Context } \\
\text { Analysis of factors } \\
\text { such as economic } \\
\text { situation, culture, } \\
\text { cohesion, commitment }\end{array}$ & $\begin{array}{l}\text { Successor Motivation } \\
\text { Needs and satisfactions } \\
\text { of successor }\end{array}$ & $\begin{array}{l}\text { Successor Training } \\
\text { and Quality } \\
\text { Predecessor-Successor } \\
\text { Relationship } \\
\text { Academic, } \\
\text { entrepreneurial training } \\
\text { and early exposure to } \\
\text { the business }\end{array}$ \\
\hline $\begin{array}{l}\text { De Massis, } \\
\text { Chua \& } \\
\text { Chrisman } \\
(2008)\end{array}$ & $\begin{array}{l}\text { Defining Roles } \\
\text { Clear role definition of } \\
\text { incumbent and } \\
\text { successor during the } \\
\text { transition and } \\
\text { composition of a team }\end{array}$ & $\begin{array}{l}\text { Evaluation } \\
\text { Evaluation of gaps } \\
\text { between the potential } \\
\text { successor's needs and } \\
\text { abilities }\end{array}$ & $\begin{array}{l}\text { Formalization of } \\
\text { criteria } \\
\text { Formalization of } \\
\text { rational and objective } \\
\text { criteria for selection } \\
\text { and communication of } \\
\text { decisions }\end{array}$ & $\begin{array}{l}\text { Training } \\
\text { Train and expose the } \\
\text { successor to the } \\
\text { business and provision } \\
\text { of sufficient feedback }\end{array}$ \\
\hline $\begin{array}{l}\text { Gersick, } \\
\text { Lansberg, } \\
\text { Desjardins } \\
\text { \& Dunn } \\
(1999)\end{array}$ & $\begin{array}{l}\text { The Trigger } \\
\text { Aging generates } \\
\text { pressure for change, } \\
\text { acknowledgment by the } \\
\text { incumbent }\end{array}$ & $\begin{array}{l}\text { Disengaging an } \\
\text { Exploring } \\
\text { Alternatives } \\
\text { Acknowledgment of } \\
\text { termination of the old } \\
\text { structure and evaluation } \\
\text { of possible future } \\
\text { directions and } \\
\text { candidates } \\
\end{array}$ & $\begin{array}{l}\text { Choosing } \\
\text { Selection of a successor } \\
\text { for making leadership } \\
\text { to continue }\end{array}$ & $\begin{array}{l}\text { Commitment to the } \\
\text { New Structure } \\
\text { Committing to this new } \\
\text { structure, the successor } \\
\text { and the support of it }\end{array}$ \\
\hline $\begin{array}{l}\text { Handler } \\
(1994) \\
\text { based on } \\
\text { Churchill \& } \\
\text { Hatten } \\
(1987)\end{array}$ & $\begin{array}{l}\text { Stage of Owner- } \\
\text { Manager } \\
\text { Incumbent as sole } \\
\text { operator and successor } \\
\text { with no role }\end{array}$ & $\begin{array}{l}\text { Stage of Training and } \\
\text { Development } \\
\text { Stage of first contact of } \\
\text { successor with the } \\
\text { business as a helper } \\
\text { whereas the incumbent } \\
\text { is still the monarch }\end{array}$ & $\begin{array}{l}\text { Stage of Partnership } \\
\text { The successor becomes } \\
\text { the manager and the } \\
\text { incumbents stays on } \\
\text { board as overseer / } \\
\text { delegator }\end{array}$ & $\begin{array}{l}\text { Stage of Transfer } \\
\text { The successor is ready } \\
\text { to be the new leader / } \\
\text { chief decision maker } \\
\text { and the incumbent rests } \\
\text { maybe as consultant }\end{array}$ \\
\hline
\end{tabular}




\begin{tabular}{|c|c|c|c|c|}
\hline $\begin{array}{l}\text { Lambrecht } \\
(2005)\end{array}$ & $\begin{array}{l}\text { Interpreneurship } \\
\text { Relationship between } \\
\text { incumbent and future } \\
\text { changes }\end{array}$ & $\begin{array}{l}\text { Written Plan } \\
\text { Planning of the transfer }\end{array}$ & $\begin{array}{l}\text { Agreement and } \\
\text { official start in the } \\
\text { family business } \\
\text { Agreement and start of } \\
\text { the successor form the } \\
\text { bottom of the ladder }\end{array}$ & $\begin{array}{l}\text { Studies, formal } \\
\text { internal education } \\
\text { and external } \\
\text { experience } \\
\text { Training of the } \\
\text { successor } \\
\end{array}$ \\
\hline $\begin{array}{l}\text { Le Breton- } \\
\text { Miller, } \\
\text { Miller \& } \\
\text { Steier } \\
(2004)\end{array}$ & $\begin{array}{l}\text { Ground Rules \& First } \\
\text { Steps } \\
\text { Start to plan the } \\
\text { succession process and } \\
\text { establishment of a } \\
\text { shared vision }\end{array}$ & $\begin{array}{l}\text { Nurturing / } \\
\text { Development of } \\
\text { Successor(s) } \\
\text { Establishing between } \\
\text { needs and prospective } \\
\text { successors abilities }\end{array}$ & $\begin{array}{l}\text { Selection } \\
\text { Design of a legitimate } \\
\text { process by establishing } \\
\text { selection criteria and } \\
\text { select successor }\end{array}$ & $\begin{array}{l}\text { Hand-off / Transition } \\
\text { Process / Installation } \\
\text { Establishing criteria for } \\
\text { the successor's } \\
\text { performance, prepare } \\
\text { incumbent and } \\
\text { successor for their new } \\
\text { roles }\end{array}$ \\
\hline $\begin{array}{l}\text { Murray } \\
(2003)\end{array}$ & $\begin{array}{l}\text { Trigger } \\
\text { Achieve readiness of } \\
\text { the incumbent to start } \\
\text { the process }\end{array}$ & $\begin{array}{l}\text { Preparation, } \\
\text { Disengagement and } \\
\text { Exploration } \\
\text { Evaluation of dreams } \\
\text { and their feasibility for } \\
\text { succession }\end{array}$ & $\begin{array}{l}\text { Choice } \\
\text { Selection of a successor } \\
\text { and what changes } \\
\text { accompanies this } \\
\text { choice }\end{array}$ & $\begin{array}{l}\text { Commitment and } \\
\text { Implementation } \\
\text { Implementation of new } \\
\text { structure and exposing } \\
\text { of the successor }\end{array}$ \\
\hline $\begin{array}{l}\text { Sharma, } \\
\text { Chua \& } \\
\text { Chrisman } \\
(2003)\end{array}$ & $\begin{array}{l}\text { Post-Succession } \\
\text { Business Strategy } \\
\text { Developing a vision or } \\
\text { strategic plan for the } \\
\text { company after } \\
\text { succession }\end{array}$ & $\begin{array}{l}\text { Post-Succession Role } \\
\text { of Incumbent } \\
\text { Defining the role of the } \\
\text { departing incumbent }\end{array}$ & $\begin{array}{l}\text { Successor Selection } \\
\text { and Training } \\
\text { Selecting and training a } \\
\text { successor }\end{array}$ & $\begin{array}{l}\text { Communication of } \\
\text { Decision } \\
\text { Communicating the } \\
\text { decision to key } \\
\text { stakeholders }\end{array}$ \\
\hline
\end{tabular}

The previous studies listed in this table separated the succession planning phase into four (e.g, Brun de Pontet et al., 2007; Handler, 1994; LeBreton-Miller et al., 2004 \& Sharma et al., 2003) up to eight (De Massis et al., 2008) individual phases. In the course of synthesizing this body of prior literature, we matched those phases to the steps proposed in this article (trigger, preparation, selection, and training) by adapting and/or merging phases. The terms provided in bold font in this table, reflecting the main description of the respective phase, are taken literally from the respective papers. 
Table 2-Trusted Advisors during Succession: An Agency Perspective

\begin{tabular}{|c|c|c|c|}
\hline Phase & Decreased Agency Costs & Increased Agency Costs & Implications \\
\hline Trigger & 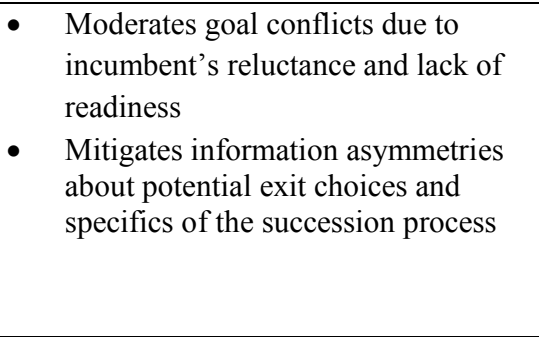 & $\begin{array}{l}\text { Goal divergence and information } \\
\text { asymmetry between an advisor and an } \\
\text { incumbent leads to: } \\
\text { - Focus on one's own goals } \\
\text { - Enforcement on the incumbent } \\
\text { leads to further reluctance } \\
\text { - Unapproved advice } \\
\text { - Over-identification of the advisor } \\
\text { with the family }\end{array}$ & $\begin{array}{ll}\text { - } & \text { Enforcement on incumbent } \\
\text { - } & \text { Enforcement on family } \\
\text { - } & \text { Provocation of hostile reactions and } \\
\text { increased reluctance to further cooperate } \\
\text { - } & \text { Biased judgment of the advisor due to } \\
\text { over-identification } \\
\text { - } & \text { Unbalanced advise }\end{array}$ \\
\hline Preparation & $\begin{array}{l}\text { Moderates stakeholders' goal } \\
\text { conflicts caused by different vision } \\
\text { or goals } \\
\text { Mitigates lack of experience, process } \\
\text { and expert knowledge (e.g., finance, } \\
\text { tax, law) by providing accurate } \\
\text { content and process information }\end{array}$ & $\begin{array}{l}\text { Goal divergence and information } \\
\text { asymmetry between an advisor and an } \\
\text { incumbent and/or successor leads to: } \\
\text { - An incumbent's too favorable } \\
\text { perspective on the business } \\
\text { - Neglect of emotions } \\
\text { - Focus on textbook, not adapted } \\
\text { solutions } \\
\text { - An advisor that is overly process } \\
\text { focused }\end{array}$ & $\begin{array}{l}\text { - Misleading information by the } \\
\text { incumbent } \\
\text { - Insufficient balance among family, } \\
\text { incumbent, and task } \\
\text { - Neglect of feelings and emotions } \\
\text { - Enhanced reluctance of incumbent to } \\
\text { withdraw }\end{array}$ \\
\hline Selection & $\begin{array}{l}\text { Moderates diverging goals related to } \\
\text { selection criteria and intra-family } \\
\text { rivalries } \\
\text { - } \\
\text { Mitigates lack of information about } \\
\text { succession options and possible } \\
\text { candidates }\end{array}$ & $\begin{array}{l}\text { Goal divergence and information } \\
\text { asymmetry between an advisor and an } \\
\text { incumbent and/or successor leads to: } \\
\text { - Neglect of firm specifics } \\
\text { - Neglect of incumbent's or } \\
\text { family's subconscious } \\
\text { preferences } \\
\text { - Advisor's lack of sensitivity } \\
\text { - } \quad \text { Advisor following own agenda }\end{array}$ & $\begin{array}{ll}\text { - } & \text { Selection of a qualified but not suitable } \\
\text { - } & \text { Euccessor } \\
\text { - } & \text { Rejection-laden discussions } \\
\text { - } & \text { Feelings of offense and reluctance } \\
\text { - } & \text { Hurt feelings } \\
\text { - } & \text { Reinforcement of conflict }\end{array}$ \\
\hline Training & $\begin{array}{ll}\text { - } & \text { Moderates goal conflict regarding } \\
\text { intensity and extent of training } \\
\text { - } \\
\text { Introduces institutional training } \\
\text { methods } \\
\text { - } & \text { Mitigates information asymmetry } \\
\text { regarding successor's abilities }\end{array}$ & $\begin{array}{l}\text { Goal divergence and information } \\
\text { asymmetry between an advisor and an } \\
\text { incumbent and/or successor leads to: } \\
\text { - A reduction of in the successor's } \\
\text { independence } \\
\text { - Non-firm-adjusted training due to } \\
\text { too-tight coaching } \\
\text { - Too much responsibility in the } \\
\text { advisor's hands } \\
\text { - No development of successor's } \\
\text { leadership ability }\end{array}$ & $\begin{array}{ll}\text { - } & \text { Reduced successor independence } \\
\text { - } & \text { Insufficient preparation of the successor } \\
\text { - } & \text { Lack of confidence in the successor } \\
\text { - } & \text { Enforcement on successor } \\
\text { - } & \text { Resentment, discontent, and suspicion by } \\
\text { - } & \text { stakeholders } \\
\text { Edging successor out of job }\end{array}$ \\
\hline
\end{tabular}




\section{FIGURES}

Figure 1-Potential Configurations of the Triadic Relationship

a) Balanced and efficient model

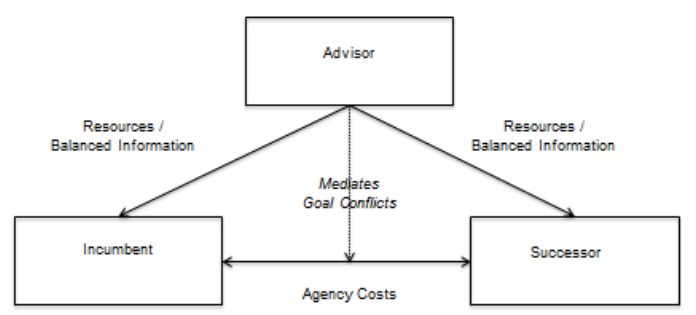

Solves the problems of the other three constellations through:
- Higher efficiency and reduced costs as only three actors are involved

- Higher robustness due to bal anced an unbiased advisor

Due to balance both parties are equally provided with the information resource

Due to balance both parties are equally provided with the
Due to balance both parties goals are equally considered

c) Successor-dominated model

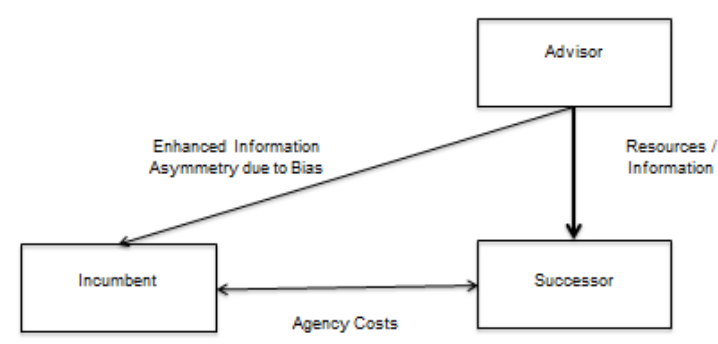

Occurs if the advisor is forward looking due to:

- Acute need for radical change in the business management (e.g. turnaround)

- Perceived future employment by the successor

- Better understanding of successor due to generational aspects b) Incumbent-dominated model

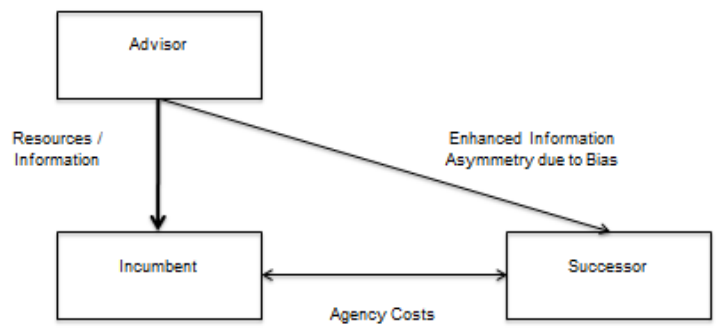

Occurs if the advisor is backward looking due to:

- Long shared emotional relationship and history with incumbent

- Commercial aspect of having being hired and paid by the incumbent for many years

d) Balanced model with two advisors

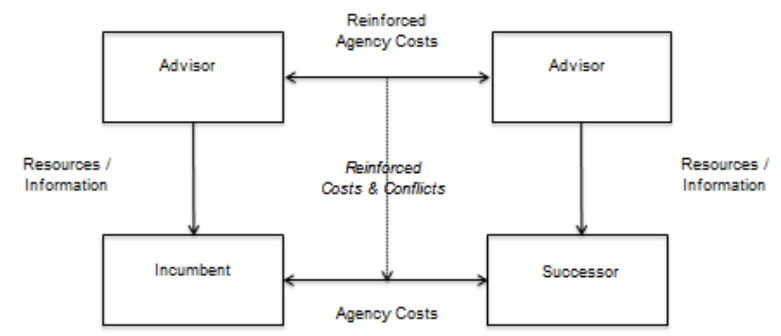

Balanced \& robust setup that, however, leads to further drawbacks due to:

- Increased costs due to higher salaries and fees

- No reduction but reinforcement of agency cost due to advisors being 